has been found the most effective agent for treating infections caused by these bacteria. ${ }^{3} \mathrm{~A}$ recent symposium on vancomycin in Geneva was told that as many as $\mathbf{4 0} \%$ of hospital staphylococci in some European centres are now methicillin resistant -but in Britain the proportion is still only around $2 \%$.

Vancomycin is recommended for patients who are allergic to penicillin and need protection against Streptococcus viridans endocarditis associated with dental extraction. Many bacteriologists would consider erythromycin preferable, however, and it is certainly cheaper. If vancomycin is chosen a single dose of $1 \mathrm{~g}$ should be injected intravenously shortly before extraction. ${ }^{4}$ Hook and Johnson ${ }^{5}$ reviewed 15 patients treated for bacterial endocarditis with vancomycin. This drug was chosen because of allergy to penicillins and cephalosporin in six patients, bacteria resistant to other antibiotics in another six patients, culture-negative endocarditis in two patients, and one patient was given vancomycin as initial treatment. Thirteen patients were cured with no serious drug toxicity. These authors recommended vancomycin as the reserve drug for Str faecalis and Str viridans endocarditis.

Vancomycin has also been used for staphylococcal infections at the site of the shunt in patients being treated with regular haemodialysis. ${ }^{6}$ Six anuric patients were treated with a $1 \mathrm{~g}$ dose of vancomycin every seven days and a satisfactory response was obtained in five. As it is bactericidal, normally almost entirely excreted by the kidney, and is not removed by dialysis, vancomycin is particularly suitable for such difficult infections.

It is, however, in the management of pseudomembranous colitis that vancomycin has found an undisputed role as firstline treatment. A regimen of $500 \mathrm{mg}$ vancomycin daily by mouth will result in the disappearance of Clostridium difficile and its toxin which are responsible for the colitis. Keighley et $a l^{7}$ gave vancomycin for the treatment of pseudomembranous colitis in a randomised controlled trial. Of 16 patients with high titres of the neutralised $\mathrm{Cl}$ difficile toxin, nine received 125 $\mathrm{mg}$ vancomycin four times a day and seven placebo. At the end of five days' treatment faecal toxins were present in one patient given vancomycin and in five controls. Vancomycin caused disappearance of $\mathrm{Cl}$ difficile from the stools in all except one patient, whereas toxicogenic strains persisted in all but one of the controls. Possibly a lower dose may be just as efficacious, and this is under investigation.

The most serious toxic effects attributed to vancomycin are tinnitus, decreased auditory acuity, and deafness, all of which have been reported when serum concentrations exceed 90-100 $\mathrm{mg} / \mathrm{l}$. Ideally peak concentrations should be kept in the region of $10-20 \mathrm{mg} / 1^{8}$ - which should be both therapeutic and safe for normal patients and also for those with diminished renal function. Vancomycin may cause thrombophlebitis, so that veins should be used in rotation and the antibiotic should be diluted in $250 \mathrm{ml}$ physiological saline or 5\% glucose and given over 30 minutes.

Vancomycin is expensive and it should be reserved for these specific indications. Intravenous treatment costs about $£ 40$ a day and oral treatment some $£ 8$ a day. Probably the high cost and potential toxicity will help to preserve this very useful agent from abuse, which experience shows usually leads to resistance emerging - a rare problem as yet with vancomycin.

RUTH BROWN Registrar

RICHARD WISE

Consultant medical microbiologist

Department of Medical Microbiology,

Dudley Road Hospital, Birmingham B18 7QH
1 Jordan DC, Mallory HD. Site of action of vancomycin on Staphylococcus aureus. Antimicrob Agents Chemother 1964;4:489-94.

2 Jordan DC, Inniss WE. Selective inhibition of ribonucleic acid synthesis in Staphylococcus aureus by vancomycin. Nature 1959;184, suppl 24: 1894-5.

${ }^{3}$ Peacock JE, Marsik FJ, Wensel R. Methicillin-resistant Staphylococcus aureus-introduction and spread within a hospital. Ann Intern Med $1980 ; 93: 526-32$.

4 Anonymous. Antibiotic cover for dental extraction. Br Med $\mathcal{F} 1975$;iii: 191

5 Hook EW, Johnson WD Jr. Vancomycin therapy of bacterial endocarditis. Am f Med 1978;65:411-5.

${ }^{6}$ Eykyn S, Phillips I, Evans J. Vancomycin staphylococcal shunt site infections in patients on regular haemodialysis. Br Med F 1970;iii:80-2.

${ }^{7}$ Keighley MRB, Burdon DW, Arabi Y, et al. Randomised controlled trial of vancomycin for pseudomembranous colitis and postoperative diarrhoea. Br Med f 1978;ii:1667-9.

${ }^{8}$ Dutton AAC, Elmes PC. Vancomycin: report on treatment of patients with severe staphylococcal infection. Br Med f 1959;i:1144-9.

\section{The way ahead for rehabilitation}

"Does every health district need a consultant in rehabilitation ?" asked Dr A O Frank (consultant in rheumatology and rehabilitation at Northwick Park Hospital) at a conference at the hospital on the way ahead for rehabilitation after reorganisation. His starting point was to question some common medical assumptions: that disease intervention should take precedence over personal and environmental intervention and the acute sector over the chronic sector. What was needed, he argued, was the "holistic" approach, taking account of the whole person in his whole life context. This view, expressed many times during the day, is hardly novel in medicine but is often difficult for hospital doctors to put into practice. Dr Frank suggested that a consultant in rehabilitation should have responsibility for the management of patients with complex disabilities, those dependent people living in the community, and those with temporary disabilities. Few physicians in the acute sector, he argued, have the time or the training to negotiate the complex support that is often necessary for helping such people to achieve or maintain the best possible life, nor are they able to attend all the case conferences and other meetings. The rehabilitation consultant is ideally placed to take on this work. Most actual rehabilitation would be carried out by other professionals; but he could not foresee a time when every consultant could realistically be expected to organise rehabilitation for his own patients. A consultant in rehabilitation moreover had an important educational function -promoting the whole-person approach to patients both in his hospital and in his district, and organising courses for local workers and visitors.

Some of the themes of the meeting were taken up in the poster displays and other material-one, for example, described a successful domiciliary physiotherapy service that had started from a research project and with careful monitoring of referrals had proved economical enough to be taken over by the area health authority. Because the flexible hours enable married women with families to do this work the scheme makes use of experienced physiotherapists who would not otherwise be employed. Speech therapy services in Harrow are also being reorganised to get patients away from hospitals to local community clinics-the subject of another poster display.

Reorganisation will mean more local responsibility for health care and increasing emphasis on rehabilitation in the community 
under the pressure of increasing strains in the acute sector. The challenge will be making the best use of resources, said Mr G Millard, Harrow district administrator. For example, he explained, we must question the way every hour of a therapist's time is used and see that the different professional skills are co-ordinated. Co-ordinating services was no less important, if they were to give maximum benefit to individuals without waste of resources; but NHS planning systems all too often got in the way of progress by being on a narrow basisplanning needed to take a more comprehensive view.

Mr Millard argued that community planning in a wider sense often worked against the interests of the elderly and frail: general practitioners, chemists, and shops were less accessible nowadays, buses sparser, and traffic more dangerous. A community health council, he said, might do better to resist the centralisation of a new general practice or to campaign for a pedestrian subway than to support more occupational therapy in the geriatric wards. He concluded with one all-embracing proposal-that all senior staff in therapy services need serious management training to enable them to think differently and more creatively and translate ideas into action for coping with reduced resources.

DAPHNE GLOAG

Staff Editor,

British Medical fournal

\section{More industrial action in the NHS}

Sadly, industrial action in the NHS is no longer the unthinkable act it was a decade ago: no section of the Service's workforce, however, can escape blame for this erosion of traditional commitment to patients' care. The Health Service is now suffering its second serious outbreak of industrial action in five years, and memories are still fresh about the consequences of the 1978-9 winter of discontent. ${ }^{1}$ The Secretary of State for Social Services has warned and union leaders have admitted that patients will suffer, despite the protection of the accident and emergency services. The Secretary of State has also reminded health authorities of the Government's previous guidance on handling industrial disputes. ${ }^{\text {a }}$

Doctors are naturally concerned about the plight of lowpaid NHS staff, whose predicament has for too long been ignored. But they will also be concerned about the plight of patients caught up in the TUC-coordinated dispute in support of a pay claim of $12 \%$. NHS management, with its hands tied firmly by the Government's $4 \%$ cash limits for pay, has offered over $6 \%$ to nurses (with a promise of some help from the Government's contingency funds) and $4 \%$ to most other staff.

To the dozen or so TUC-affiliated unions in the disputethe Royal College of Nursing is balloting its 195000 members on the nurses' offer-4\% is unacceptable, bearing in mind the rate of inflation and the low pay of many of their members, some of whom, the Confederation of Health Service Employees has argued, would be better off on the dole. Furthermore, the level of recent pay settlements for senior civil servants, generals, and judges, who like the doctors in 1978-80, have received a catching-up award-albeit cut by $5 \%$ by the Government (p 1572)- - has fuelled the unions' determination. While doctors are not directly concerned with this pay dispute as their remuneration has been dealt with by their Review Body their 1982 award $^{2}$ has been abated because the Government declined to reinstate the $3 \%$, cut it made last year, ${ }^{3}$ and they have told the Secretary of State ( $p$ 1572) of their "anxiety that other NHS staff groups might secure more favourable treatment as a result of industrial action."

Typically, the parties to the dispute are laying down barrages of figures and percentages, with the Secretary of State pointing out in a speech to the Medical Journalists Association the increased resources (in real terms) given to the NHS since 1979 and the steadily rising number of staff, including an expected rise of 10000 for 1982 (p 1573). Thus two seemingly irreconcilable factors stand out in this crisis: the pay of too many NHS staff is inadequate but the large number of them means that the cost of a fair increase is more than the Government says the country can afford. It is on this point that what is at present a management/union dispute over a pay claim could move on to the more contentious plane of political priorities for Health Service spending, and with other unions promising supporting action ${ }^{4}$ a major political confrontation cannot be ruled out. Such a development would, however, do immense damage to the NHS.

The local effects of the industrial action so far are patchy, though union ballots and branch meetings suggest a groundswell of support that may make this a protracted dispute, whose effects will be felt in general practice as well as in hospitals. The one-day strike called for 19 May (after this $B M f$ goes to press) should give a clearer indication of what is in store. In any case, many doctors will already be frustrated at the damage this dispute will do to a service currently struggling with reorganisation, inflation, and cash limits. They can, however, help to minimise the effects and protect patients from the worst consequences of the dispute by keeping cool heads, fostering communications with management and local union leaders-which may not be easy in some districts-and, where appropriate, seeking advice from their local professional representatives or the BMA centrally. The consultants' leader, Mr David Bolt, has written to medical executive committees with practical advice, stating firmly that, "the decision regarding the urgency of any particular case is entirely one for the consultant responsible for that patient and you must stand firmly by this principle" ( $p$ 1573). The BMA earlier issued advice for the profession (1 May, p 1348).

Whether the dispute is eventually resolved by arbitration, capitulation by the unions, or financial concessions from the Government is unclear at present. One thing is, however, clear: the NHS needs a better machinery for settling pay than the outdated and complex Whitley Committee system. Some type of independent review, not only to judge outside comparisons but also to rationalise the tangled internal pay relativities, would seem a sensible solution, and one that is already in sight for the nurses ( $p$ 1565). Perhaps the setting up of such a system might form part of the ultimate bargain that will inevitably have to be struck to end this unhappy dispute.

\footnotetext{
${ }^{1}$ Anonymous. Industrial anarchy in the NHS. Br Med F 1979;i :364. 1a Anonymous. Handling industrial disputes. Br Med f 1979;ii:1604.

2 Anonymous. Review Body Report 1982. Br Med f 1982;284:1487.

3 Anonymous. Doctors' pay. Br Med f 1981 ;282:1651.

4 Anonymous. COHSE warning of all-out strikes. The Times 1982 May 13:2.
} 